\title{
Membangun Aplikasi Sistem Informasi Komunitas Motor Berbasis Android (Studi Kasus : GSX Community Boyolali- Klaten)
}

\author{
Fairus Yuliagustin a,1, Saiful Bahri ${ }^{\text {b,2,* }}$, Dwi Kristiani a,3 \\ ${ }^{\text {a }}$ Fakultas Ilmu Komputer, Universitas Boyolali, Jl. Pandanaran No.405, Boyolali, 57315, Indonesia \\ ${ }^{\mathrm{b}}$ Fakultas Pertanian, Universitas Slamet Riyadi, Jl. Sumpah Pemuda No. 18 Kadipiro, Surakarta 57136, Indonesia \\ ${ }^{1}$ fay.fairuzlubis@gmail.com , ${ }^{2}$ irsaifulbahrimkom@gmail.com , ${ }^{3}$ dwikristiani45@gmail.com \\ * Koresponsendi penulis
}

ARTICLE INFO

Article history

Menerima 25 Oktober 2019

Revisi 27 Januari 2020

Diterima 30 Januari 2020

Kata Kunci

Community

Android

PIECES

UML

\section{ABSTRACT}

Research titled utilization of android application to support the Information System and Registration of new members of the GSX community who are secretariat in Boyolali-Semarang Street Dusun I, Winong, Boyolali, Boyolali. The research began from March 18, 2019 until June 18, 2019, with the aim of a) Building an Android-based application in accordance with the problems that have been analyzed, b) Designing an Android-based application program that can help facilitate prospective members who wish to register GSX Community Boyolali-Klaten members, c) Creating an android-based application so that members can more easily access and find the latest information about the community. The research methodology used is the PIECES Method, object modeling using UML. The results achieved are an android application to facilitate the registration of new members and providing information.

This is an open access article under the CC-BY-SA 4.0 license.

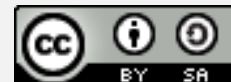

\section{Pendahuluan}

Pada saat ini banyak sekali "komunitas" yang muncul di lingkungan masyarakat. Komunitas-komunitas yang hadir di masyarakat ini pun bermacam-macam. Komunitas adalah suatu kelompok sosial di suatu masyarakat yang terdiri dari beberapa individu yang saling berinteraksi di lingkungan tertentu dan umumnya memiliki ketertarikan yang sama, misalnya kesamaan minat, kesamaan profesi, kesamaan agama, kesamaan tempat tinggal, dan lain-lain". [1]

Salah satu contoh komunitas yang sedang banyak diminati oleh masyarakat pada saat ini adalah komunitas motor. Mulai dari remaja hingga orang dewasa ikut bergabung di komunitas motor. Komunitas motor yang muncul di masyarakat pun sangat banyak dari berbagai macam tipe dan merk motor yang ada di pasaran,mulai dari jenis motor sport, matic, modif, dan lain-lain. Salah satu komunitas motor yang ada di Boyolali adalah GSX Community Boyolali-Klaten. Komunitas motor ini terdiri dari pengendara motor GSX-R, GSX-S, dan juga Bandit yang diproduksi dan dikeluarkan oleh Suzuki. Lokasi sekretariat komunitas ini berada di Jalan Boyolali-Semarang, Dusun I, Kelurahan Winong, Kecamatan Boyolali, Kabupaten Boyolali.

Saat ini komunitas GSX Community Boyolali-Klaten melakukan pendataan pendaftaran anggota baru dengan cara mengisi form tertulis, membagikan info kegiatan komunitas dengan mengirim pesan kepada masing-masing anggota atau memasang gambar yang berisi data kegiatan di sosial media pengurus komunitas. Hal tersebut dirasa kurang efektif dikarenakan untuk form pendaftaran anggota baru dibawa oleh salah satu pengurus, sehingga dapat menghambat proses pendataan 
pendaftaran anggota baru apabila pengurus tersebut tidak bisa hadir. Form yang berupa lembaran kertas juga lebih sulit dalam pengarsipan dan apabila diperlukan harus memakan waktu untuk mencari data satu persatu. Kendala juga terjadi apabila anggota ingin mengetahui info mengenai kegiatan dan juga info-info lainnya mengenai komunitas, anggota sulit untuk mengakses info-info tersebut. Anggota yang ingin mencari info apabila tidak mengikuti media sosial pengurus yang bersangkutan, maka mereka harus menghubungi secara langsung dan belum tentu langsung mendapatkan respon.

Seiring dengan perkembangan teknologi yang ada saat ini, kebutuhan dan keinginan masyarakat terhadap layanan teknologi berbasis IT pun menjadi bervariatif. Untuk memenuhi kebutuhan dan tuntutan diatas, dibutuhkan program aplikasi untuk smartphone berbasis Android yang dapat dengan mudah dipakai oleh para pengguna smartphone. Android merupakan perangkat bergerak pada sistem operasi untuk telepon seluler yang berbasis linux[2].

Berdasarkan permasalahan diatas maka dirumuskan masalahnya adalah Bagaimana merancang aplikasi android untuk mempermudah calon anggota komunitas melakukan pendaftaran dan mempermudah anggota komunitas mengakses informasi yang dibutuhkan dengan cepat. Sedangkan tujuan penelitiannya adalah untuk merancang aplikasi android untuk mempermudah calon anggota komunitas melakukan pendaftaran dan mempermudah anggota komunitas mengakses informasi yang dibutuhkan dengan cepat.

\section{Tinjauan Pustaka}

Penelitian ini dilakukan tidak terlepas dari hasil penelitian-penelitian sejenis yang pernah dilakukan sebagai bahan perbandingan berdasarkan topik penelitian yaitu tentang membangun aplikasi sistem informasi berbasis android. Penelitian terdahulu antara lain:

Penelitian yang pernah dilakukan oleh [3] berjudul Rancang Bangun Aplikasi Komunitas Mancing Berbasis Android. Tujuan dari penelitian ini adalah untuk membangun sebuah aplikasi yang dapat menjadi wadah untuk para anggota komunitas mancing. Metode penelitian melalui tiga tahap yaitu melakukan analisis permasalahan, melakukan studi literatur dengan mengumpulkan referensi yang diperoleh dari buku-buku, dan membuat pemodelan aplikasi yang akan digunakan dalam pembangunan aplikasi. Hasil penelitiannya berupa aplikasi yang dapat dijalankan via platform android. Pengujian aplikasi dilakukan dengan metode blackbox dengan hasil pengujian menyatakan bahwa tiga modul utama berjalan dengan baik dan layak dipergunakan untuk menjadi sarana pertukaran informasi anggota komunitas mancing.

Penelitian yang pernah dilakukan oleh [4] dengan judul Registrasi Calon Siswa Baru Berbasis Mobile Android di Sekolah Menengah Atas Negeri 9 Manado. Tujuan penelitian ini adalah untuk membantu calon siswa baru untuk melakukan pendaftaran menggunakan perangkat mobile dan membantu pihak sekolah untuk mengolah data pendaftaran. Metode penelitian menggunakan metode AUP (Agile Unified Process). Hasil penelitian berupa aplikasi android registrasi calon siswa baru SMAN 9 Manado yang dapat membantu calon siswa untuk melihat informasi dari sekolah dan menghubungi panitia penerimaan siswa baru SMAN 9 Manado secara online, serta memudahkan pihak sekolah dalam mengolah data pendafatarn siswa baru.

Penelitian dengan judul Pembuatan Aplikasi Sistem Informasi Monitoring Kegiatan Mahasiswa Berbasis Web dan Android Client yang dilakukan oleh [5] mempunyai tujuan penelitian untuk membuat suatu rancang bangun aplikasi sistem informasi monitoring kegiatan mahasiswa berbasis web dan android client. Metode yang digunakan dalam penelitian adalah metode $R A D$ (Rapid Application Development) dan pengujian aplikasi menggunakan metode blackbox. Hasil yang diperoleh dari penelitian ini adalah aplikasi sistem informasi monitoring kegiatan mahasiswa berbasis web dan android client terimplementasi dengan baik dan dengan hasil pengujian menggunakan metode blackbox dimana seluruh fungsi menu dalam aplikasi telah berjalan sesuai dengan fungsinya. 


\section{Metode Penelitian}

Prosedur kerja yang dilakukan untuk menyelesaikan permasalahan penelitian ini adalah menggunakan metode PIECES (Performance, Information, Economics, Control, Efficiency, dan Service). Metode PIECES adalah metode analisis sebagai dasar untuk memperoleh pokokpokok permasalahan yang lebih spesifik. Dalam menganalisis sebuah sistem, biasanya akan dilakukan terhadap beberapa aspek antara lain adalah kinerja, informasi, ekonomi, keamanan aplikasi, efisiensi dan pelayanan pelanggan. [6]

Metode ini menggunakan enam variabel evaluasi yaitu :

a) Performance (kinerja). Unsur performance ini memiliki peran penting untuk menilai apakah proses atau prosedur yang ada masih mungkin ditingkatkan kinerjanya, dan melihat sejauh mana dan seberapa handalkah suatu sistem informasi dalam berproses untuk menghasilkan tujuan yang diinginkan. Hal-hal yang menjadi ukuran dalam performance yaitu : 1. Throughput, yaitu jumlah pekerjaan/ output/ deliverables yang dapat dilakukan/ dihasilkan pada saat tertentu; 2. Response time, yaitu waktu yang dibutuhkan untuk menyelesaikan serangkaian kegiatan untuk menghasilkan output tertentu.

b) Information (informasi). Menilai apakah informasi mempunyai nilai guna untuk pengguna dalam hal konten, ketepatan waktu, akurasi, dan format informasi. Dalam hal ini dapat diukur dengan : 1. Masukan (inputs) : keperluan memasukkan suatu data, hingga di mana data disimpan. 2. Keluaran (outputs) : terjadinya produksi hasil keluaran berupa tampilannya.

c) Economic (ekonomi). Menilai apakah prosedur yang ada saat ini masih dapat ditingkatkan manfaatnya (nilai gunanya) atau diturunkan biaya penyelenggaraannya.

d) Control (pengendalian). Menilai apakah prosedur yang ada saat ini masih dapat ditingkatkan sehingga kualitas pengendalian menjadi semakin baik, dan kemampuannya untuk mendeteksi kesalahan/ kecurangan menjadi semakin baik pula.

e) Efficiency (efisiensi). Menilai apakah prosedur yang ada saat ini masih dapat diperbaiki, sehingga tercapai peningkatan efisiensi operasi. Kemampuan mengolah data dengan meminimalisasi langkah kerja yang dianggap tidak perlu.

f) Service (layanan). Menilai apakah layanan sistem dapat diandalkan, fleksibel, dan ditingkatkan kemampuannya. Kriteria pada yang service ini, antara lain: siapakah pengguna layanan, adakah ada berbagai tipe pengguna, apakah sistem memperhatikan pengguna, petunjuk dan cara penggunaan perangkat harus dimasukkan dalam sistem, serta perlukah menyimpan dokumen.

Dalam penelitian ini menggunakan teknik pengumpulan data, yaitu : 1) Observasi atau pengamatan dilakukan secara langsung pada kegiatan yang berhubungan dengan pendaftaran anggota baru dan kegiatan-kegiatan lain yang mencakup informasi mengenai GSX Community Boyolali-Klaten; 2) Wawancara dilakukan dengan mengajukan pertanyaan kepada narasumber mengenai objek penelitian. 3) Studi Pustaka dengan cara mencari, mengumpulkan, dan membaca buku, artikel maupun jurnal untuk memperoleh informasi yang berhubungan dengan permasalahan yang akan dibahas serta mempelajarinya melalui bacaan yang relevan sebagai sumber untuk mendukung dalam penyusunan penelitian ini.

Tahap selanjutnya desain sistem menggunakan pendekatan berorientasi objek, Tool yang digunakan untuk pendekatan objek adalah UML. UML (Unified Modeling Language) adalah bahasa pemodelan untuk sistem atau perangkat lunak yang berparadigma berorientasi objek. Pemodelan (modelling) sesungguhnya digunakan untuk penyederhanaan permasalahan-permasalahan yang kompleks sedemikian rupa sehingga lebih mudah dipelajari dan dipahami. [7] 
Alur pertama yaitu menentukan Functional Requirement. Berdasarkan hasil wawancara dengan salah satu pengurus GSX Community Boyolali-Klaten mendapatkan informasi bahwa GSX Community Boyolali-Klaten dalam proses pendaftaran anggota baru masih menggunakan formulir pendaftaran yang dalam pengisian masih dilakukan dengan cara tulis tangan, penyimpanan formulir dan data anggota juga masih diarsipkan oleh salah satu pengurus sehingga sulit dan tidak efektif saat data dibutuhkan. Informasi mengenai kegiatan komunitas dapat dilihat dari grup chat media sosial komunitas yang masih dirasa kurang efektif, karena apabila informasi yang dibagikan oleh pengurus tertutup chat dari anggota maka anggota lain yang belum membaca banyak yang tidak mengetahui informasi yang dibagikan.

Dari hasil wawancara tersebut diatas, dapat disimpulkan bahwa sistem pendaftaran dan pembagian informasi di GSX Community Boyolali-Klaten kurang optimal karena belum adanya media online atau wadah khusus komunitas yang dapat membantu proses pendaftaran, pendataan serta pembagian informasi komunitas GSX ini, maka diperlukan adanya aplikasi berbasis android agar dapat dimanfaatkan untuk mengatasi permasalahan tersebut diatas sehingga lebih efektif dan dapat diakses dengan mudah.

Dari permasalahan diatas, maka functional requirement sistem informasi komunitas yang sederhana adalah a) Sistem harus dapat memproses pendaftaran anggota baru yang ingin bergabung ke dalam komunitas; b) Pendaftaran anggota baru harus memiliki data pribadi dan data kendaraan; c) Approval calon anggota berdasarkan data pribadi dan data kendaraan; d) Sistem harus dapat menampilkan informasi komunitas motor.

Alur kedua membuat Class Diagram (sederhana) seperti Gambar 1, sesuai dengan functional requirement diatas, agar tidak terjadi cross sistem maka menggunakan istilah yang akan digunakan saat proses pendaftaran sebagai berikut : a) Pendaftaran anggota baru : Pendaftaran; b) Idenditas diri calon anggota : Data Pribadi; c) Data lengkap kendaraan : Data Kendaraan; d) Proses persetujuan masuk sebagai anggota komunitas : Approval.

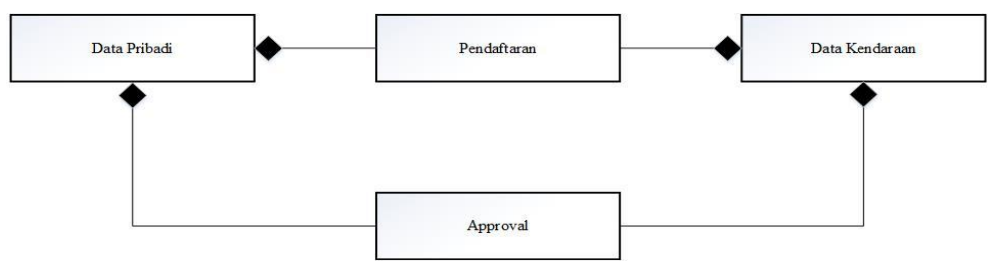

Gambar 1. Class Diagram 
Alur ketiga membuat Use Case pendaftaran anggota baru seperti Gambar 2. Penjelasannya adalah ada 4 (empat) aktor yang terlibat yaitu Anggota, Calon Anggota, Penanggungjawab dan Admin. Admin dapat melakukan beberapa proses yaitu login, melihat list pendaftaran, approval pendaftaran calon anggota, update kegiatan, update forum, update informasi, melakukan voting, dan melakukan laporan. Calon Anggota dapat melakukan proses pendaftaran, mengisi dan mengubah data calon anggota. Sedangkan penanggung jawab dapat melakukan proses melihat kegiatan, melihat forum, melihat informasi dan menerima laporan.

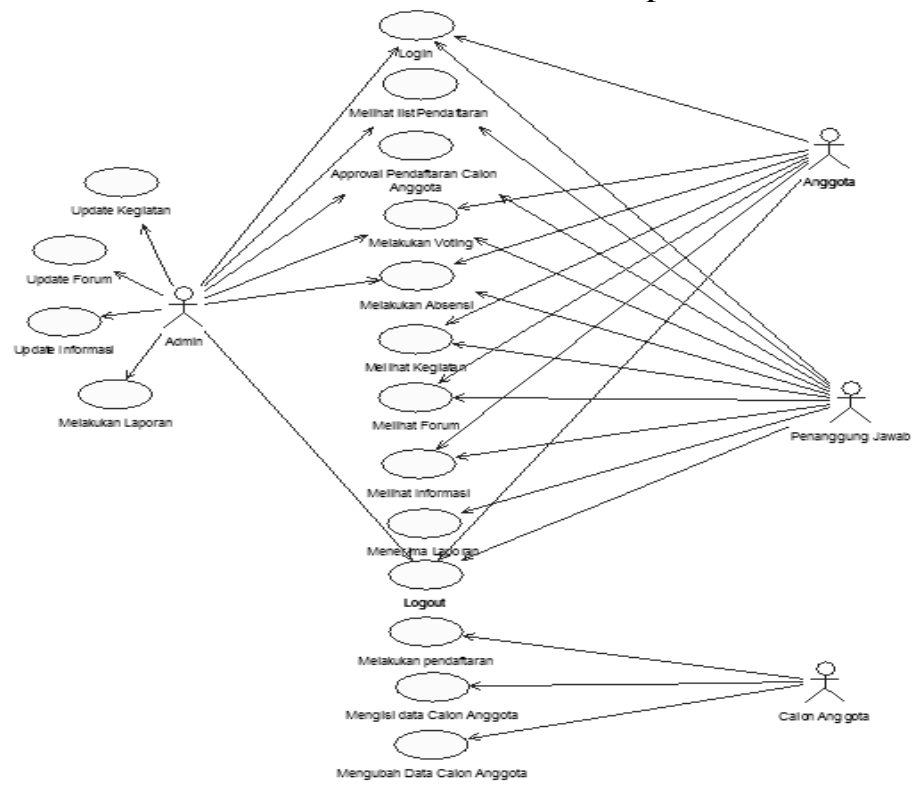

Gambar 2. Use Case 
Activity diagram adalah sesuatu yang menggambarkan berbagai alur aktivitas dalam sistem yang sedang dirancang, bagaimana masing-masing alir berawal, decision yang mungkin terjadi dan bagaimana mereka berakhir. Pada Gambar 3 akan dijelaskan activity diagram pendaftaran anggota baru. Calon anggota baru akan mendapatkan link download pendaftaran anggota baru dan menginstal aplikasi ini. Selanjutnya sistem akan menampilkan halaman login dan menampilkan form pendaftaran. Selanjutnya calon anggota mengisi form pendaftaran yang berisi data pribadi maupun data kendaraan. Jika sudah lengkap maka Admin akan menerima notifikasi pendaftaran anggota baru dan melakukan persetujuan atau approval. Notifikasi approval akan diterima oleh penanggungjawab selanjutnya akan diberikan ID dan nomer anggota untuk calon anggota yang mendaftar tersebut.

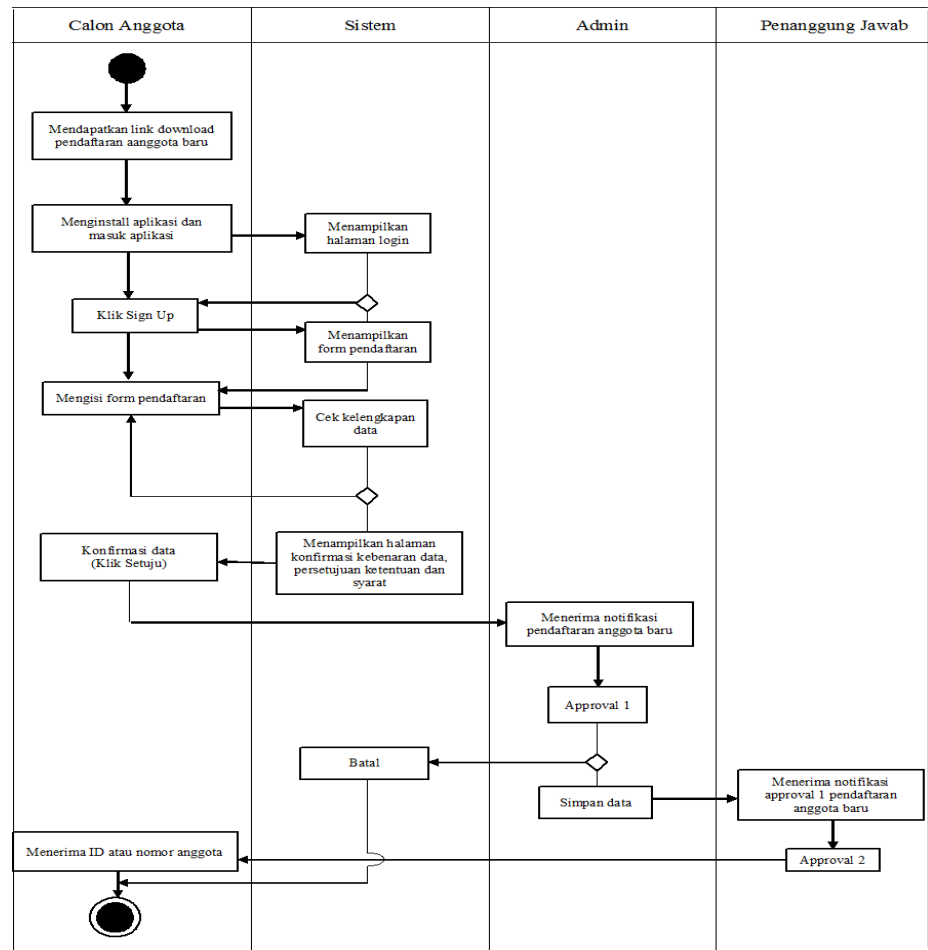

Gambar 3. Activity diagram pendaftaran anggota baru

Sequence Diagram digunakan untuk menggambarkan skenario atau rangkaian langkahlangkah yang dilakukan sebagai sebuah respon dari suatu kejadian/even untuk menghasilkan output tertentu. Sequence diagram pendaftaran baru dapat dilihat pada Gambar 4. Untuk melakukan pendaftaran anggota baru, calon anggota harus memilih menu pendaftaran dihalaman utama, kemudian mengisi form pendaftaran dengan data yang lengkap dan valid agar tidak terjadi kegagalan. Setelah calon anggota mengisi data, sistem akan memproses data dan kemudian melakukan proses validasi. Apabila data tidak valid, sistem akan mengirimkan pesan kesalahan atau gagal, jika data valid maka sistem akan meneruskan proses konfirmasi pendaftaran dan selanjutnya akan mengirimkan pesan tunggu persetujuan.

Sedangkan sequence diagram approval anggota baru seperti pada Gambar 5 dapat dijelaskan sebagai berikut: Proses approval admin akan memilih menu list pendaftaran. Sistem akan menampilkan list data calon anggota yang sudah mendaftar, kemudian admin memilih calon anggota yang datanya valid dan memenuhi persyaratan. Apabila data valid dan memenuhi syarat maka admin akan memilih data calon anggota tersebut untuk selanjutnya di proses oleh sistem. Data anggota akan ditampilkan, kemudian admin akan menyetujui atau mengapprove calon anggota yang memenuhi syarat. 

Vol. 4, No. 1, Januari 2020, pp. 17-26

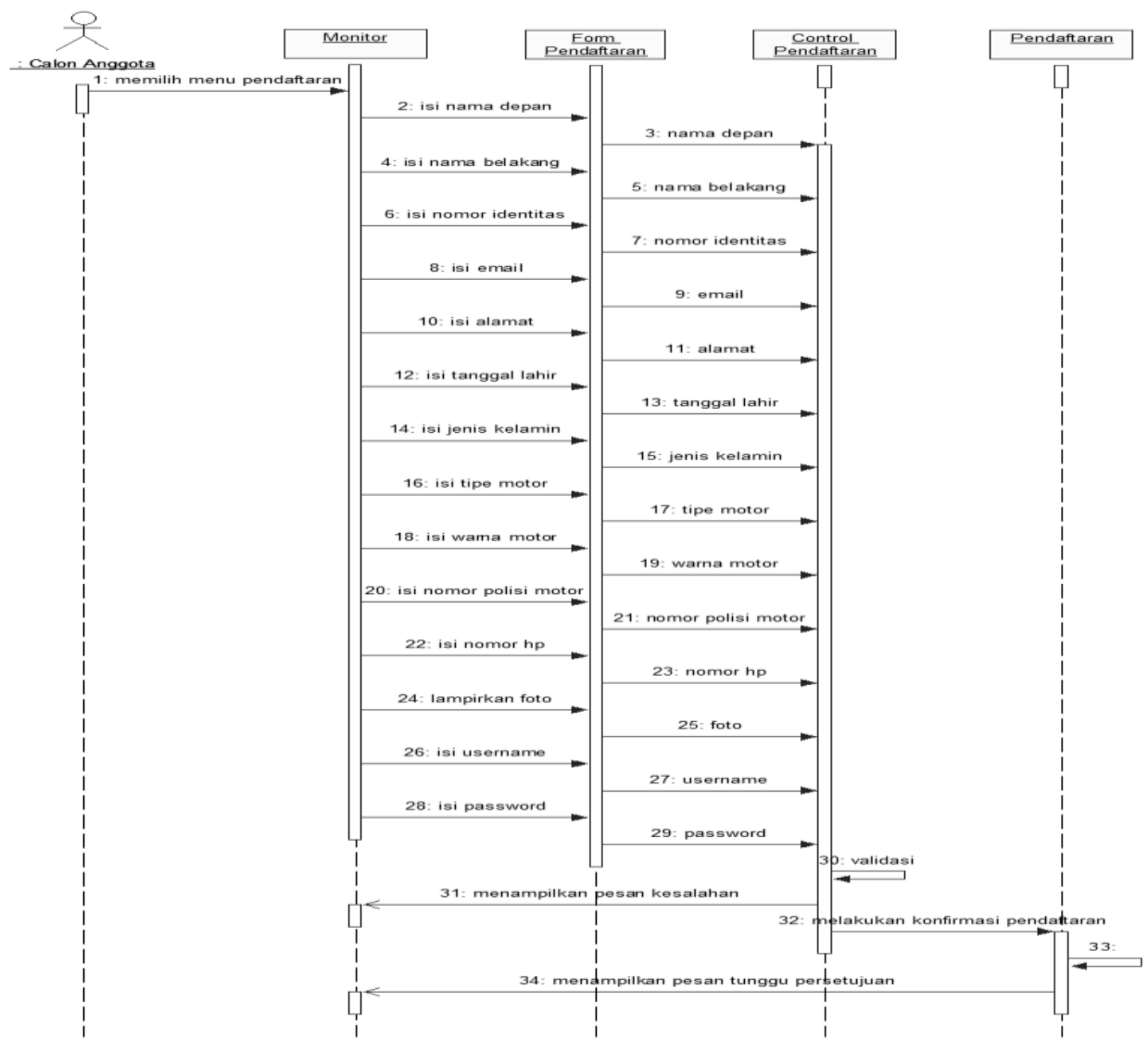

Gambar 4. Sequence Diagram Pendaftaran

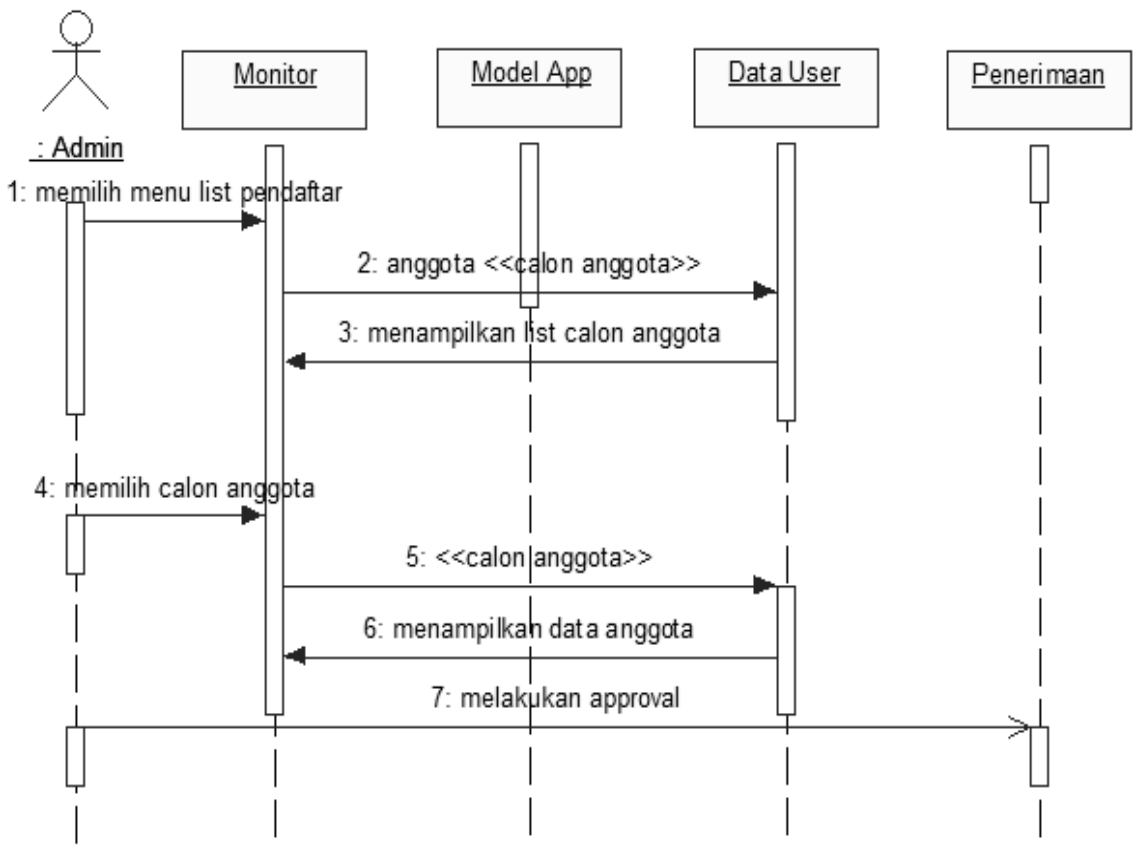

Gambar 5. Sequence Diagram Approval Anggota Baru 


\section{Hasil dan Pembahasan}

Implementasi ini merupakan penerapan yang diperoleh dari analisa kebutuhan sampai dengan konstruksi untuk mewujudkan aplikasi android yang diusulkan. Aplikasi android ini dirancang sebagai media pendaftaran dan penyebaran informasi secara online bagi GSX Community Boyolali-Klaten yang selama ini hanya melakukan pendaftaran secara offline, sehingga dengan menggunakan aplikasi ini pendaftaran tidak harus datang ketempat dan juga anggota dapat melihat informasi pada aplikasi kapanpun.

Halaman utama seperti pada Gambar 6 berisi header di bagian paling atas yang terdapat nama komunitas dan menubar. Dibagian body berisi gambar - gambar yang menunjukkan isi dari beberapa bagian menu. Pada bagian paling bawah terdapat footer yang berisi ringkasan kontak dan social media yang dapat dihubungi dan diakses.

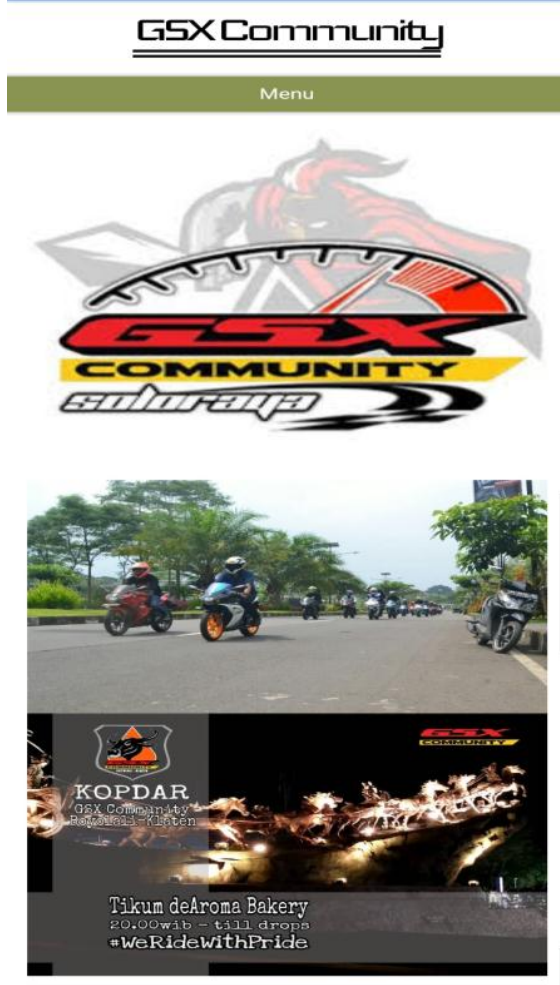

Gambar 6. Tampilan Home

Apabila pengguna belum terdaftar sebagai anggota sehingga belum memiliki username dan password yang digunakan untuk login ke aplikasi, maka pengguna diharuskan mengisi form register terlebih dahulu. Data harus diisi secara lengkap dan sesuai dengan data pribadi. Setelah selesai, klik "Daftar" pada bagian bawah halaman.
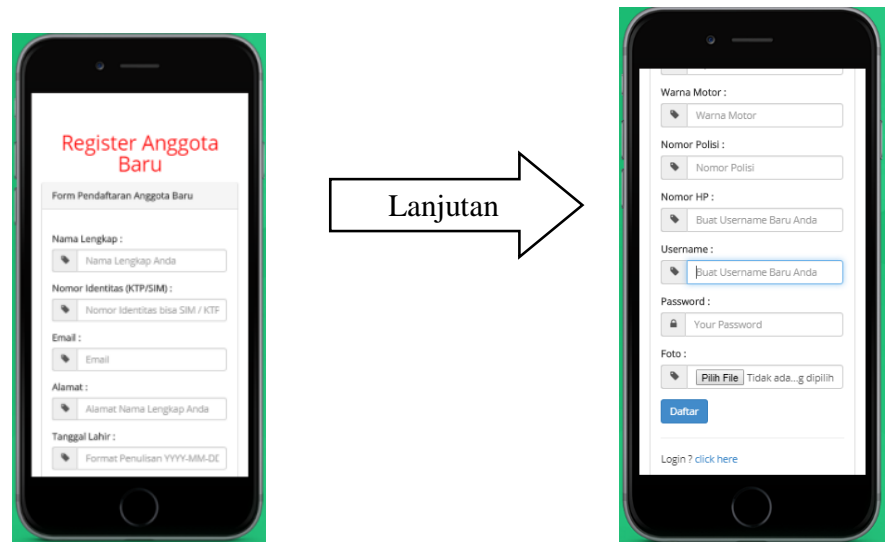

Gambar 7. Tampilan Register Anggota Baru 
Gambar 7 adalah tampilan halaman login saat sudah menjadi anggota. Anggota dapat memasukkan username dan password yang telah diisi pada form register atau pendaftaran. Username dan password dapat digunakan untuk login setelah di Approve oleh admin dan status keanggotaannya menjadi aktif.

Halaman Menu Pengguna memiliki menu-menu yang dapat diakses oleh pengguna atau anggota komunitas. Menu-menu tersebut mengandung informasi-informasi yang bersangkutan dengan komunitas. Tampilan menu home seperti Gambar 8, tampilan menu profil sejarah seperti Gambar 9, tampilan profil visi misi seperti Gambar 10, tampilan meu agenda seperti Gambar 11, tampilan menu berita seperti Gambar 12, tampilan menu form seperti Gambar 13, tampilan menu galery seperti Gambar 14, tampilan menu anggota seperti Gambar 15 dan tampilan menu contact us seperti Gambar 16.

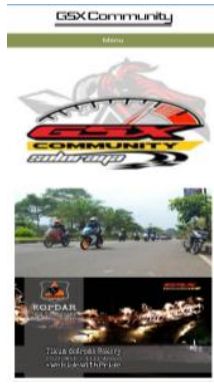

Gambar 8. Tampilan Menu Home

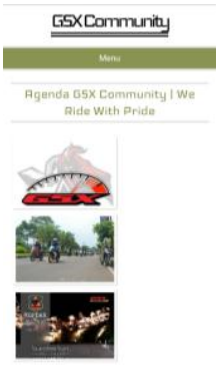

Gambar 11. Tampilan Menu Agenda

coscammunity

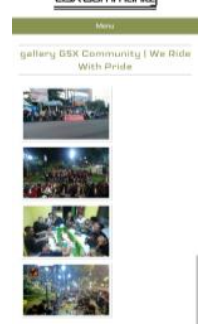

Gambar 14. Tampilan Menu Gallery

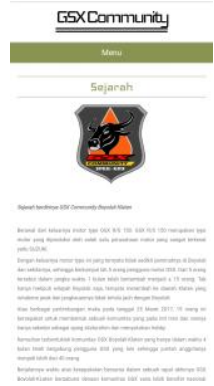

Gambar 9. Tampilan Menu Profil Sejarah

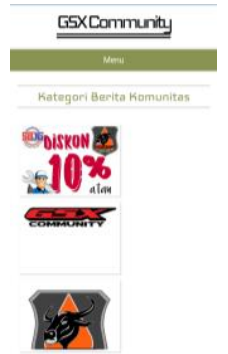

Gambar 12. Tampilan Menu Berita

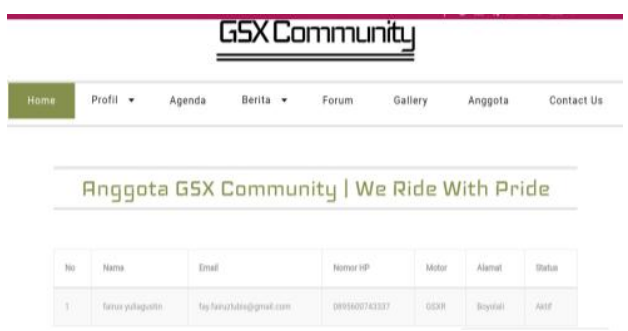

Gambar 15. Tampilan Menu Anggota

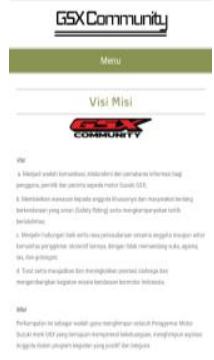

Gambar 10. Tampilan Profil Visi Misi

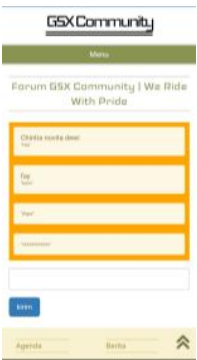

Gambar 13. Tampilan Menu Forum

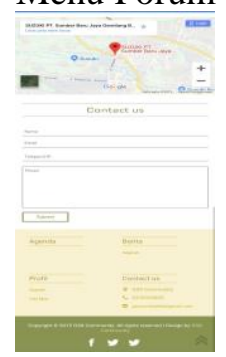

Gambar 16. Tampilan Menu Contact Us

Halaman admin seperti Gambar 17 merupakan halaman untuk login admin agar dapat mengakses aplikasi dengan cara input username dan password. Tampilan utama setelah admin berhasil login ke sistem aplikasi. Terdapat beberapa menu yang ditampilkan dihalaman utama admin antara lain dashboard, berita, agenda, forum, gallery, users atau admin, dan anggota. Untuk keluar dari halaman admin dapat klik pilihan logout. Sedangkan tampilan halaman utama admin seperti pada Gambar 18 . 


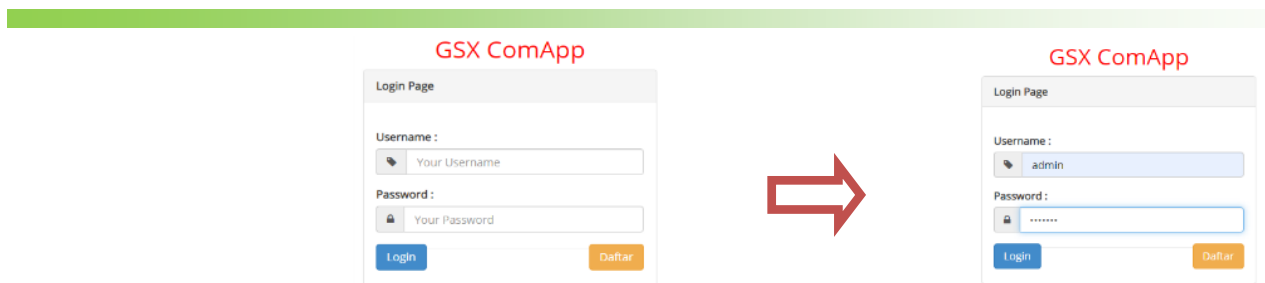

Gambar 17. Tampilan login Admin

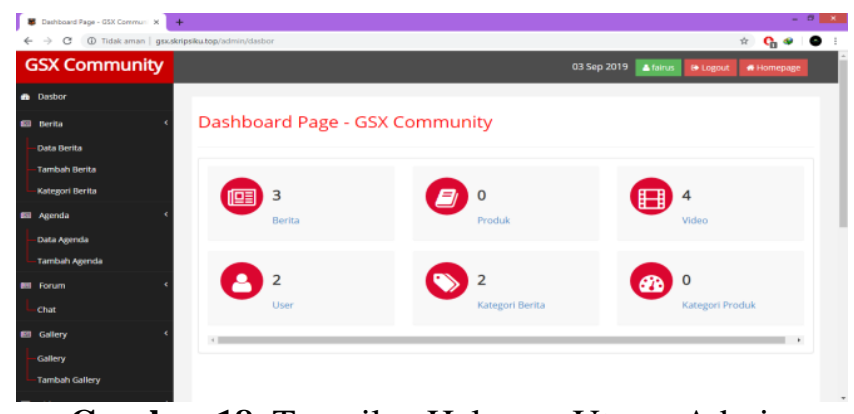

Gambar 18. Tampilan Halaman Utama Admin

Hasil implementasi selanjutnya dianalisa kinerjanya menggunakan metode PIECES yang sudah ditetapkan sebelumnya. Hasil evaluasinya adalah sebagai berikut:

a) Performance (kinerja). Kinerja diukur berdasarkan Throughput, yaitu jumlah pekerjaan/ output/ deliverables yang dapat dilakukan/ dihasilkan pada saat tertentu, hasilnya adalah dapat melakukan pekerjaan lebih dari satu sekaligus seperti melihat data pendaftaran yang masuk dan membuat persetujuan. Sedangkan untuk Response time, yaitu waktu yang dibutuhkan untuk menyelesaikan pendaftaran anggota baru bisa diselesaikan dengan cepat atau tidak memakan waktu sampai 5 (lima) menit.

b) Information (informasi). Informasi yang diberikan mempunyai nilai guna untuk pengguna, seperti informasi tentang kegiatan yang dilakukan oleh komunitas ini.

c) Economic (ekonomi). Hasil aplikasi ini dapat menurunkan biaya dalam penyelenggaraan pendaftaran anggota baru. Dalam hal ini berkurangnya penggunaan kertas untuk pengisian formulir pendaftaran.

d) Control (pengendalian). Aplikasi ini dilengkapi dengan kontrol masukan data sehingga dapat mendeteksi kesalahan dan memberikan pesan jika terjadi kesalahan dalam pengisian form.

e) Efficiency (efisiensi). Aplikasi yang dihasilkan dapat mengurangi prosedur dalam pendaftaran anggota baru, yaitu lebih singkat dalam hal persetujuan dan pemberian ID dan nomer anggota dapat secara langsung diberikan melalui sistem.

f) Service (layanan). Aplikasi ini dapat melayani siapa saja yang akan menjadi anggota baru dan aplikasi ini menyediakan petunjuk cara penggunaannya.

\section{Kesimpulan}

Berdasarkan hasil penelitian yang telah diuraikan diatas maka dapat disimpulkan bahwa :

a) Sesuai dengan permasalahan yang telah dianalisa menggunakan metode Pieces, bahwa sistem informasi berbasis android perlu dibuat dan dibangun untuk menyelesaikan permasalahan yang ada; b) Aplikasi ini dapat digunakan sebagai pendaftaran berbasis android yang diberi nama GSX Community App diharapkan dapat membantu komunitas GSX Community Boyolali Klaten untuk melakukan pendaftaran anggota baru dan mengakses informasi secara online; c) Aplikasi dapat membantu calon anggota agar tidak perlu datang langsung kelokasi dalam pengisian form pendaftaran dan membantu pengurus dalam mengelola data anggotanya, tidak memerlukan banyak ruang untuk menyimpan data atau pengarsipan data dan juga lebih menghemat pengeluaran komunitas yang biasanya digunakan untuk mencetak form dan undangan.

Sedangkan saran yang dapat diberikan adalah aplikasi dapat ditambah dengan menu marketplace yang dapat digunakan para anggota untuk menawarkan produknya yang berhubungan dengan motor atau menu bengkel yang berisikan informasi lokasi bengkel terdekat ketika sedang melakukan perjalanan jarak jauh.

Fairus Yuliagustim et.al (Membangun Aplikasi Sistem Informasi Komunitas Motor Berbasis Android (Studi Kasus : GSX Community Boyolali-Klaten)) 


\section{Daftar Pustaka}

[1] N. Sora. ( 2015 ). "Pengertian Komunitas : Arti, Manfaat, Jenis, dan Contohnya". ( Online ), (http://www.pengertianku.net/2015/05/pengertian-komunitas-dan-menurut-para-ahli.html, diakses 24 Februari 2019).

[2] Yudhanto, Yudha. Wijayanto, Ardhi. (2017). Mudah Membuat dan Berbisnis Aplikasi Android dengan Android Studio. Jakarta : PT Elex Media Komputindo.

[3] Saputra, Edo Halim. Arsa, Suyadna, I Made. Oka, Widyantara, I Made. ( 2017 ). E-Journal Spektrum. "Rancang Bangun Aplikasi Komunitas Mancing Berbasis Android". 4 (2), 159-166. ISSN 2684-9186. Universitas Udayana. ( Online ), (https://ojs.unud.ac.id/index.php/spektrum/ article/download/36430/22002/, diakses tanggal 10 September 2019).

[4] Palilingan, Y.R., Kenneth. Sinsuw, A.E., Alicia, ST, MT. Najoan, B.N., Xaverius, ST, MT. ( 2014 ). E-journal Teknik Elektro dan Komputer. "Registrasi Calon Siswa Baru Berbasis Mobile Android di Sekolah Menengah Atas Negeri 9 Manado", 3 (3), 26-30. Electronic-ISSN: 2685-368X. Universitas Sam Ratulangi Manado. ( Online ), (https://ejournal.unsrat.ac.id/index.php/elekdankom/article/view/5313, diakses 10 September 2019)

[5] Risnandar, Erdi (2015). "Pembuatan Aplikasi Sistem Informasi Monitoring Kegiatan Mahasiswa Berbasis Web dan Android Client". ( Online ), (https://lib.unnes.ac.id/22122/, diakses tanggal 10 September 2019).

[6] Gunawan, Indra, Betara (2013). "Definisi Analisa Metode Pieces." ( Online ), (http://www.kktara.xyz/2013/11/definisi-analisis-metode-pieces.html, 55, diakses tanggal 24 Februari 2019)

[7] Pratama, Rahmatullah, Aditya. ( 2019 ). "Belajar Unified Modeling Language (UML) - Pengenalan". ( Online ), (https://www.codepolitan.com /unified-modeling-language-uml, diakses 26 Februari 2019) 